\title{
Oxygen stress reduces zoospore survival of Phytophthora species in a simulated aquatic system
}

Ping Kong ${ }^{*}$ and Chuanxue Hong

\begin{abstract}
Background: The genus Phytophthora includes a group of agriculturally important pathogens and they are commonly regarded as water molds. They produce motile zoospores that can move via water currents and on their own locomotion in aquatic environments. However, zoosporic response to dissolved oxygen, an important water quality parameter, is not known. Like other water quality parameters, dissolved oxygen concentration in irrigation reservoirs fluctuates dramatically over time. The aim of this study was to determine whether and how zoospore survival may be affected by elevated and low concentrations of dissolved oxygen in water to better understand the aquatic biology of these pathogens in irrigation reservoirs.

Results: Zoospores of P. megasperma, P. nicotianae, P. pini and P. tropicalis were assessed for survival in 10\% Hoagland's solution at a range of dissolved concentrations from 0.9 to $20.1 \mathrm{mg} \mathrm{L}^{-1}$ for up to seven exposure times from 0 to $72 \mathrm{~h}$. Zoospore survival was measured by resultant colony counts per $\mathrm{ml}$. Zoospores of these species survived the best in control Hoagland's solution at dissolved oxygen concentrations of 5.3 to $5.6 \mathrm{mg} \mathrm{L}^{-1}$. Zoospore survival rates decreased with increasing and decreasing concentration of dissolved oxygen, depending upon Phytophthora species and exposure time. Overall, P. megasperma and P. pini are less sensitive than P. nicotianae and P. tropicalis to hyperoxia and hypoxia conditions.

Conclusion: Zoospores in the control solution declined over time and this natural decline process was enhanced under hyperoxia and hypoxia conditions. These findings suggest that dramatic fluctuations of dissolved oxygen in irrigation reservoirs contribute to the population decline of Phytophthora species along the water path in the same reservoirs. These findings advanced our understanding of the aquatic ecology of these pathogens in irrigation reservoirs. They also provided a basis for pathogen risk mitigation by prolonging the turnover time of runoff water in recycling irrigation systems via better system designs.
\end{abstract}

Keywords: Phytophthora species, Aquatic ecology, Zoospore survival, Dissolved oxygen

\section{Background}

Phytophthora species, a group of fungal-like destructive plant pathogens, are known as water molds [1-4]. They produce motile zoospores that can spread through irrigation systems from runoff water retention basins at ornamental crop production facilities and cause severe plant diseases and crop losses. Over 40 species of Phytophthora have been recovered from irrigation systems and natural waterways [5].

\footnotetext{
* Correspondence: pkong@vt.edu

Virginia Tech, Hampton Roads Agricultural Research and Extension Center, Virginia Beach, VA 23455, USA
}

\section{Biomed Central}

Zoospores generally are short-live and their survival is subject to environmental stresses. Majority of zoospores survive for less than $24 \mathrm{~h} \mathrm{[6-8].} \mathrm{Zoospore} \mathrm{survival} \mathrm{of} \mathrm{individ-}$ ual species in aquatic environments depends upon water $\mathrm{pH}[7,9]$, electrical conductivity (EC) [6], and $\mathrm{CO}_{2}[10,11]$.

Dissolved oxygen is another important water quality parameter. Dissolved oxygen concentration in agricultural reservoirs varies among water sources and fluctuates seasonally as well as diurnally within the same sources due to activities of phytoplankton, change of temperature and atmosphere pressure [12]. Dissolved oxygen concentration in lakes, streams, and ponds that receive runoff from nurseries was $9.0,7.0$ and $12.0 \mathrm{mg} \mathrm{L}^{-1}$, respectively [13]. 
Dissolved oxygen concentrations in runoff water containment basin that was also an irrigation reservoir varied from 0.3 to $26.5 \mathrm{mg} \mathrm{L}^{-1}$ over time [13]. These oxygen concentrations are much lower than the atmospheric oxygen level of $21 \%$ or $276 \mathrm{mg} \mathrm{L}^{-1}$ based on the air density of $1.2 \mathrm{~g} \mathrm{~m}^{-3}$ with $23.2 \%$ of oxygen at the sea level (http:// www.en.wikipedia.org/wiki/Atmosphere_of_Earth).

Dissolved oxygen is known to affect the survival of fish and other aquatic organisms including algae [14]. Whether and how dissolved oxygen may affect zoospore survival of Phytophthora species in irrigation reservoirs is not known. Previous studies in relation to oxygen have focused primarily on other propagules in terrestrial rather than zoospores in aquatic environments. Species of Phytophthora grew well in oxygen concentrations from $0.04 \%$ to $21 \%$ (or $0.5-276 \mathrm{mg} \mathrm{L}^{-1}$ ) in soil or on agar media $[15,16]$. Mycelia can grow under a wide range of oxygen conditions as long as its concentration was below $1.6 \%$ (or $21 \mathrm{mg} \mathrm{L}^{-1}$ ) $[15,17]$. However, Phytophthora species produce sporangia in water films under a narrow range of dissolved oxygen concentrations. For instance, sporangium production was prolific at an oxygen level of $5 \%$ (or $\geq 65 \mathrm{mg} \mathrm{L}^{-1}$ ) but production nil to few at $1 \%$ (or $13 \mathrm{mg} \mathrm{L}^{-1}$ ) [18]. Few oospores were produced at atmospheric oxygen levels of $276 \mathrm{mg} \mathrm{L}^{-1}$ or higher while numerous were produced at much lower levels at 13 and $65 \mathrm{mg} \mathrm{L}^{-1}[16,17,19]$. Disease development delayed in plants inoculated with P. cinnamomi at an oxygen range of $0.9-2.3 \mathrm{mg} \mathrm{L}^{-1}$ in aeroponic and hydroponic systems $[20,21]$. These studies demonstrate that different propagules may require different levels of oxygen for production, growth and survival.

Here, we report the effects of elevated and low concentrations of dissolved oxygen in a simulated aquatic system on zoospore survival for several Phytophthora species. The aim of this study was to develop a better understanding of aquatic ecology of Phytophthora species, establishing a base for devising sustainable mitigation strategies for these pathogens in irrigation water.

\section{Methods}

\section{Base medium, dissolved oxygen treatment systems}

The base medium used for all the experiments in this study was $10 \%$ Hoagland's solution. The full strength solution was prepared with Hoagland's basal salt mixture (MP Bio, Solon, OH, USA) and adjusted with $\mathrm{NaOH}$ to have a final $\mathrm{pH}$ of 7.0. To maintain a stable $\mathrm{pH}$, the stock solution was buffered with $1 \mathrm{mM}$ MES hydrate (Sigma, St. Louis, MO USA) and stored at $4^{\circ} \mathrm{C}$ until use. The stock solution was freshly diluted with $\mathrm{dH}_{2} \mathrm{O}$ at 1:10. The diluted solution was then placed in $500-\mathrm{ml}$ glass bottles leaving no or little room for air. Bottle filling was done $18-20 \mathrm{~h}$ ahead of experiment to allow temperature equilibrium. As measured with EcoSense ${ }^{\circ}$
DO 200 meter (YSI Inc, South Burlington, VT, USA), dissolved oxygen concentration in the control solution (CK) as static $10 \%$ Hoagland's solution at $23^{\circ} \mathrm{C}$ was 5.3 to $5.6 \mathrm{mg} \mathrm{L}^{-1}$.

\section{Potential side effect of nitrogen as replacement gas on zoospore survival}

Although nitrogen does not react with water it dissolves in water at $20 \mathrm{mg} \mathrm{L}^{-1}$ at $20 \mathrm{C}$ (http://www.lenntech.com/ periodic/water/nitrogen/nitrogen-and-water.htm). To determine whether dissolved $\mathrm{N}_{2}$ in the solution from bubbling pure $\mathrm{N}_{2}$ directly affects zoospore survival, assays were performed with four selected Phytophthora species. Three treatments were included: (i) CK-the control Hoagland's solution, (ii) $\mathrm{N}_{2}$-the same solution bubbled with pure $\mathrm{N}_{2}$ for $10 \mathrm{~min}$ to reduce dissolved oxygen concentration to $0.9 \mathrm{mg} \mathrm{L}^{-1}$, and (iii) $\mathrm{dN}_{2}$-the bubbled solution with $\mathrm{N}_{2}$ for $10 \mathrm{~min}$ was poured into open containers allowing to restore dissolved oxygen concentration to $5.3 \mathrm{mg} \mathrm{L}^{-1}$ over a 48-h period. The details of species and isolates as well as the zoospore survival assay protocol are described below. For simplicity, only data from $P$. tropicalis are presented.

\section{Elevation and reduction of dissolved oxygen concentration in the base medium}

Dissolved oxygen elevation and reduction was achieved by bubbling pure oxygen $\left(\mathrm{O}_{2}\right)$ or nitrogen $\left(\mathrm{N}_{2}\right)$ into $10 \%$ Hoagland's solution in the bottles. For dissolved oxygen concentration elevation, oxygen was bubbled at $0.5 \mathrm{~L} \mathrm{~min}^{-1}$ for $0,15,30,45,60,75,90,120$ or 150 seconds. Dissolved oxygen concentrations were measured immediately after bubbling. This experiment was repeated three times. The dissolved oxygen concentration in the solution after bubbling 90 seconds were out of range of the DO 200 meter which can measure up to $18 \mathrm{mg} \mathrm{L}^{-1}$. Data from repeating experiments were pooled after homogeneity test. Prior to the further analysis, bubbling time was divided into 15second segments and assigned numerical values with 1 for the first (0-15 seconds), 2 for the second (16-30 seconds), and 5 for the fifth (61-75 seconds). Correspondingly, dissolved oxygen elevation was computed for individual 15 -second time segments with 3.2, 2.4, 2.2, 1.8, and $1.5 \mathrm{mg} \mathrm{L}^{-1}$ for the first, second, third, fourth and fifth (Table 1). The speed of dissolved oxygen concentration elevation was then related to these 15-second time segments using Proc GLM (SAS Institute, Cary, North Carolina, USA). A resultant model was used to make elevated concentrations of dissolved oxygen as desired in the zoospore survival assays. To track the dynamics of dissolved oxygen concentration in the solutions, additional measurements were taken at 2, 4, 8 and $24 \mathrm{~h}$ following oxygen bubbling. All bottles were sealed with parafilm then capped tightly after bubbling and each measurement. 
Table 1 Dissolved oxygen (DO) levels in 10\% Hoagland's solution generated by oxygen $\left(\mathrm{O}_{2}\right)$ or nitrogen $\left(\mathrm{N}_{2}\right)$ bubbling

\begin{tabular}{|c|c|c|c|c|c|c|c|c|}
\hline \multicolumn{6}{|c|}{$\mathrm{O}_{2}$ bubbling at $0.5 \mathrm{~L} \mathrm{~min}^{-1}$} & \multicolumn{3}{|c|}{$\mathrm{N}_{2}$ bubbling at $0.4 \mathrm{~L} \mathrm{~min}^{-1}$} \\
\hline Time (Sec) & $\begin{array}{c}\text { Assigned time } \\
\text { segment value }(x)\end{array}$ & $\begin{array}{l}\text { Measured DO } \\
\left(\mathrm{mg} \mathrm{L}^{-1}\right)^{\mathrm{y}}\end{array}$ & SD & $\begin{array}{c}\text { Predicted DO increase } \\
\text { within time segment }(y)^{z}\end{array}$ & $\begin{array}{l}\text { Predicted total } \\
\text { DO in solution }\end{array}$ & $\begin{array}{l}\text { Time } \\
\text { (Min) }\end{array}$ & $\begin{array}{l}\text { Measured DO } \\
\left(\mathrm{mg} \mathrm{L}^{-1}\right)\end{array}$ & SD \\
\hline 0 & 0 & 5.6 & 0.2 & - & 5.6 & 0 & 5.3 & 0.1 \\
\hline 15 & 1 & 8.8 & 0.0 & 3.2 & 8.8 & 2 & 2.0 & 0.0 \\
\hline 30 & 2 & 11.2 & 0.2 & 2.5 & 11.3 & 5 & 1.2 & 0.0 \\
\hline 45 & 3 & 13.4 & 0.3 & 2.1 & 13.4 & 10 & 0.9 & 0.1 \\
\hline 60 & 4 & 15.2 & 0.2 & 1.8 & 15.4 & 20 & 0.9 & 0.0 \\
\hline 75 & 5 & 16.7 & 0.2 & 1.6 & 16.7 & 30 & 1.0 & 0.1 \\
\hline 90 & 6 & Out of range & ND & 1.4 & 18.1 & & & \\
\hline 120 & 8 & Out of range & ND & 1.1 & 19.2 & & & \\
\hline 150 & 10 & Out of range & ND & 0.9 & 20.1 & & & \\
\hline
\end{tabular}

${ }^{y}$ These numbers are meter readings and the meter cannot measure dissolved oxygen above $18.0 \mathrm{mg} \mathrm{L}^{-1}$.

${ }^{\mathrm{z}}$ These values are calculated based on a regression model: $\mathrm{y}=3.2-\ln (\mathrm{x})$, as generated from the SAS analysis.

For dissolved oxygen reduction, pure nitrogen gas was bubbled into the Hoagland's solution in the bottles at $0.4 \mathrm{~L} \mathrm{~min}^{-1}$ for $2,5,10,20$, or $30 \mathrm{~min}$. Dissolved oxygen concentrations were measured immediately after bubbling subsequently selected for the zoospore survival studies. Similarly, the dynamics of dissolved oxygen concentration in the solutions was tracked following the $\mathrm{N}_{2}$ bubbling.

\section{Phytophthora species and zoospore suspension preparation}

Irrigation water isolates of four Phytophthora species: P. megasperma (isolate 42D2), P. nicotianae (45H1), P. pini (previously, P. citricola, 43H1) and P. tropicalis (7G9) were used in this study [7]. These species had differential responses to $\mathrm{pH}$ stress [22].

Cultures were maintained and zoospore suspensions were prepared as described previously [7]. Briefly, zoospore suspension was prepared with agar plugs from one-week-old cultures. The plugs were grown in $10 \%$ clarified V8 juice broth at room temperature for 7 days for P. nicotianae and P. tropicalis, and 3 days for P. megasperma and $P$. pini. After the media were removed, the cultures were then rinsed with sterile distilled water (SDW), drained and exposed to fluorescent light for 24 $48 \mathrm{~h}$ for $P$. nicotianae and P. tropicalis, $8 \mathrm{~h}$ for P. megasperma. For $P$. pini, the cultures were flooded with SDW again then incubated under lights for $8 \mathrm{~h}$ to facilitate sporangium production. After the light exposure, water was drained then plates were refilled with chilled sterile soil water extract to trigger zoospore release. Zoospore yields reached $>10^{4} \mathrm{~mL}^{-1}$ after $30 \mathrm{~min}$ for $P$. nicotianae and $P$. tropicalis, and after overnight for $P$. megasperma and $P$. pini. Zoospore suspensions were filtered through a layer of sterile miracloth to remove cultural plugs and mycelia. Zoospore concentrations were determined with a haemocytometer.

\section{Zoospore survival assays}

Three sets of zoospore survival assays were performed to determine the impacts of (i) potential side effect of nitrogen as a replacement gas for oxygen in the Hoagland's solutions, (ii) elevated and (iii) low concentrations of dissolved oxygen in comparison with the regular concentration in the control solutions that were not bubbled with any gas $\left(\mathrm{O}_{2}\right.$ or $\left.\mathrm{N}_{2}\right)$. The elevated concentrations of dissolved oxygen tested were 11.3, 15.2, 18.1, 19.2, $20.1 \mathrm{mg} \mathrm{L}^{-1}$, and the normal concentration of $5.6 \mathrm{mg} \mathrm{L}^{-1}$ (control) along with reduced concentrations of dissolved oxygen at 2.0, 1.2 , and $0.9 \mathrm{mg} \mathrm{L}^{-1}$. The dissolved oxygen treatments were made as described above.

A certain volume of fresh zoospore suspension was added to each bottle to make a final concentration of 50 zoospores $\mathrm{mL}^{-1}$ without altering the dissolved oxygen concentration in the Hoagland's solutions. Bottles were gently inverted twice then two or three 1-mL aliquots were taken out from each bottle within $10 \mathrm{~min}$. Each aliquot was spread onto a 90-mm plate with PARP-V8 agar [23]. Additional samples were taken at 2, 4, 8, and $24 \mathrm{~h}$ in the elevated dissolved oxygen assays. Two more samples were taken for the reduced dissolved oxygen assays at 48 or $72 \mathrm{~h}$, respectively. The plates were placed at room temperature for 2 to 3 days. Emerging colonies in each plate were counted and the colony counts were used to measure zoospore survival in the Hoagland's solutions at various concentrations of dissolved oxygen for different exposure times. Each experiment included three replicate bottles and was repeated at least three times.

\section{Statistical analyses of zoospore survival assay data}

Data of zoospore survival rates as measured by resultant colony counts from repeating assays were examined for homogeneity then analyzed separately with Proc ANOVA. Mean survival rates of three replicates from 6 or 9 plates 
were separated by the least significant difference (LSD) at $P=0.05$. Linear regression analyses were performed to determine whether and how the elevated concentrations of dissolved oxygen may affect the colony counts by Phytophthora species and exposure time. Similar analyses also were conducted to determine whether and how the level of dissolved oxygen reduction in the Hoagland's solutions from its normal concentration $\left(5.3 \mathrm{mg} \mathrm{L}^{-1}\right)$ may influence the colony counts of four Phytophthora species at different exposure times.

\section{Results and discussion}

\section{Effect of dissolved nitrogen on zoospore survival}

In preliminary studies using hydrazine hydrate and $\mathrm{CO}_{2}$ to manipulate dissolved oxygen concentration in Hoagland's solution, we found that both chemicals themselves significantly reduced zoospore survival [10,22]. Nitrogen was used as replacement gas for oxygen in previous investigations into the mycelial growth of Aphanomyces euteiches [24], Phytophthora cactorum [15], Pythium ultimum [25], and spore germination of Phytophthora citrophthora, Phytophthora nicotianae, and Thielaviopsis basicola in liquid medium [17,26]. Nitrogen also was used in hydroponic systems to investigate root infection of avocado (Persea americana), shortleaf pine (Pinus echinata) and loblolly pine (Pinus taeda) by Phytophthora cinnamomi $[21,27,28]$. However, none of these studies evaluated the potential impact of high concentration of nitrogen itself. Thus, the first assay performed was to determine whether nitrogen itself impacts zoospore survival.

Hoagland's solution at $10 \%$ strength was used as base medium and four species of Phytophthora were included in this assay. Zoospore survival was compared among three solutions: (i) control solutions (CK) as a static $10 \%$ Hoagland's solution with dissolved oxygen at $5.6 \mathrm{mg} \mathrm{L}^{-1}$, (ii) bubbled with nitrogen $\left(\mathrm{N}_{2}\right)$ to reduce dissolved oxygen concentration to $0.9 \mathrm{mg} \mathrm{L}^{-1}$, and (iii) degassed after nitrogen bubbling $\left(\mathrm{dN}_{2}\right)$ with a final concentration of dissolved oxygen similar to that in the control solution. No difference in colony counts was observed between the control and degassed solutions $\left(\mathrm{dN}_{2}\right)$ regardless of exposure time as illustrated by $P$. tropicalis (Figure 1 ). As expected, more colony counts were consistently resulted from the degassed solutions $\left(\mathrm{dN}_{2}\right)$ than those not degassed $\left(\mathrm{N}_{2}\right)$ solutions (Figure 1$)$. These results indicate that dissolved nitrogen in the Hoagland's solution had no effect on the zoospore survival. Similar results were obtained for the other three species evaluated in this study. These results implicate nitrogen had no impact on spore germination, mycelial growth, and root infection of avocado and pines in those previous studies $[15,17,21,24,25,27,28]$ and it is a good replacement gas for the subsequent assays in this study.

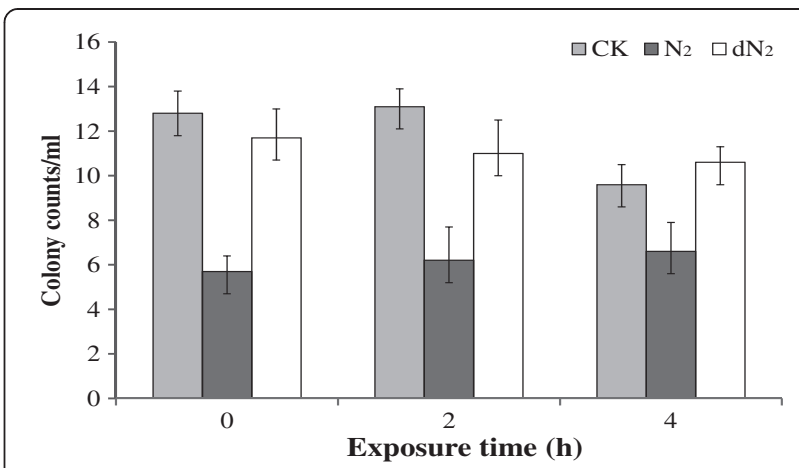

Figure 1 Impact of dissolved $\mathrm{N}_{2}$ and oxygen on zoospore survival of Phytophthora tropicalis. CK, 10\% Hoagland's solution ( $\mathrm{pH} 7$ ) at dissolved oxygen (DO) of $5.3 \mathrm{mg} \mathrm{L}^{-1}$ without $\mathrm{N}_{2}$ bubbling; $\mathrm{N}_{2}$, same solution bubbled with $\mathrm{N}_{2}$ for 10 min to reduced DO to $0.9 \mathrm{mg} \mathrm{L}^{-1} ; \mathrm{dN}_{2}$, same solution bubbled with $\mathrm{N}_{2}$ for 10 min then aerated until DO returned to $5.3 \mathrm{mg} \mathrm{L}^{-1}$; Each column is a mean of the three replicates, topped with standard deviations of the mean.

\section{Elevation and reduction of dissolved oxygen concentration with gas bubbling}

The second assays conducted were to establish the relationship between dissolved oxygen concentration and gas bubbling time and to understand the post-bubbling dynamics of dissolved oxygen concentration in the solutions. Dissolved oxygen concentrations in the 10\% Hoagland's solution increased with increasing oxygen bubbling time (Table 1). But the speed of dissolved oxygen elevation in the solution decreased at every additional 15-second segment of bubbling time. This relationship was best fitted $(\mathrm{R}=0.9842)$ as:

$$
y=3.2-\ln (x)
$$

in which $y$ is the speed of dissolved oxygen elevation $\left(\mathrm{mg} \mathrm{L}^{-1}\right)$ per 15 seconds; $\mathrm{x}$ is the number of 15 -second segments $(x>0)$.

The concentrations of dissolved oxygen in the solutions after being bubbled with oxygen for 90, 120 and 150 seconds were estimated to be 18.1, 19.2, and $20.1 \mathrm{mg} \mathrm{L}^{-1}$, respectively (Table 1 ).

Dissolved oxygen concentrations decreased with increasing nitrogen bubbling time up to 10 minutes (Table 1). Extended nitrogen bubbling for 20 and $30 \mathrm{~min}$ did not further decrease the dissolved oxygen concentration in the Hoagland's solutions (Table 1). Thus, these 20 and 30 min treatments were excluded from the subsequent studies.

There was little change in the dissolved oxygen concentration within the $24 \mathrm{~h}$ of oxygen and nitrogen bubbling (Figure 2). However, dissolved oxygen concentration in the Hoagland's solutions was gradually restored to its original concentration of 5.3 to $5.6 \mathrm{mg} \mathrm{L}^{-1}$ within 72 hours of bubbling regardless of gas treatment $\left(\mathrm{O}_{2}\right.$ or $\left.\mathrm{N}_{2}\right)$. 

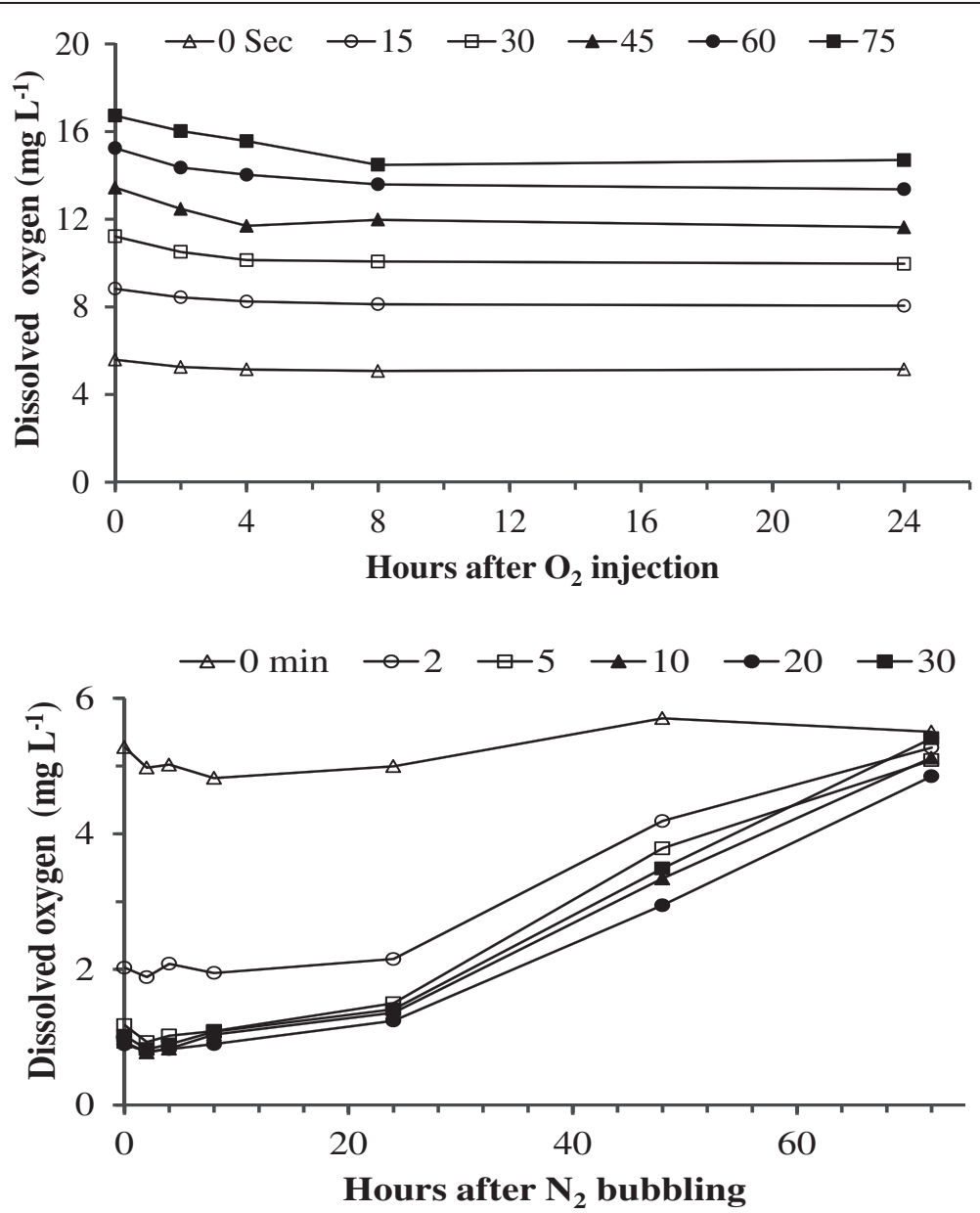

Figure 2 Dynamics of dissolved oxygen levels in $10 \%$ Hoagland's solution following $\mathrm{O}_{2}$ (top) and $\mathrm{N}_{2}$ (bottom) bubbling.

Effect of elevated concentrations of dissolved oxygen on zoospore survival

Among the four species assessed in this study, only zoospores of $P$. megasperma in the control bottles at dissolved oxygen concentration of $5.6 \mathrm{mg} \mathrm{L}^{-1}$ consistently declined with increasing exposure time as reflected in the intercept of the linear models (Table 2). The greatest colony count of this species was observed at 10 -min and 2-h exposures and the least at 24-h exposure. It is not known at this time why the greatest colony counts of P. nicotianae, P. pini and P. tropicalis occurred at 2- or 4-h instead of 10-min exposures.

As indicated by the slope of linear models, zoospore survival of all four species were negatively impacted by elevated concentrations of dissolved oxygen for most exposure times (Table 2). For instance, the colony counts of $P$. megasperma decreased with increasing dissolved oxygen concentration at $10-\min (P<0.0001)$, 2-h $(P=0.0010)$ and 4 -h exposures $(P=0.0324)$. The colony counts of the other three species decreased with increasing dissolved oxygen concentration at all exposure times with a few exceptions. As indicated by the slope of linear models, the greatest rate of decrease in colony counts occurred at 4-h exposure with 0.7 colony per unit of dissolved oxygen increase for $P$. nicotianae $(P=0.0001), 1.4$ for $P$. pini $(P<0.0001)$, and 0.6 for $P$. tropicalis $(P=0.0004)$, respectively. The only exceptions were observed in $P$. megasperma at $24 \mathrm{~h}, P$. nicotianae at $10 \mathrm{~min}$ and $24 \mathrm{~h}$, as well as $P$. pini at $10 \mathrm{~min}$.

These results indicated that zoospore survival in runoff water containment basins is subjected to fluctuations of dissolved oxygen concentration in particular of hyperoxia conditions although there are slightly differences among the four species assessed in this study. P. megasperma was least affected by elevated concentrations of dissolved oxygen as was by a range of $\mathrm{pH}$ in a previous study [7]. Differences in oxygen response were previously observed among oomycetes and fungi. By their oxygen response, these fungi and oomycetes can be grouped into three categories. First, mycelial growth is directly proportional to atmospheric oxygen level with the optimum at $21.0 \%$. This pattern is exemplified by $P$. nicotianae 
Table 2 Linear regression analyses of colony counts (y) and elevated concentrations of dissolved oxygen in the Hoagland's solutions $(x)$ after being bubbled with pure oxygen by Phytophthora species and exposure time ${ }^{z}$

\begin{tabular}{llccc}
\hline Species & Exposure $(\mathbf{h})$ & Intercept $(\boldsymbol{a})$ & Slope $(\boldsymbol{b})$ & $\boldsymbol{P}$ \\
\hline P. megasperma & 0 (10 min) & 24.1 & -0.4 & $<0.0001$ \\
& 2 & 22.0 & -0.3 & 0.0010 \\
& 4 & 15.3 & -0.2 & 0.0324 \\
& 8 & 11.9 & -0.2 & 0.4980 \\
P. nicotianae & 24 & 9.5 & 0.1 & 0.1902 \\
& 0 & 2.8 & 0.2 & 0.0032 \\
& 2 & 23.5 & -0.4 & 0.0011 \\
P. pini & 4 & 33.0 & -0.7 & 0.0001 \\
& 8 & 22.5 & -0.2 & 0.0377 \\
& 24 & 7.0 & 0.2 & 0.0202 \\
& 0 & 7.6 & 0.3 & 0.0032 \\
& 2 & 42.3 & -0.9 & 0.0033 \\
& 4 & 43.1 & -1.4 & $<0.0001$ \\
& 8 & 21.2 & -0.3 & 0.0175 \\
& 24 & 17.7 & -0.4 & 0.0006 \\
& 0 & 13.3 & -0.2 & 0.0794 \\
& 2 & 21.2 & -0.4 & 0.0025 \\
& 4 & 22.0 & -0.6 & 0.0004 \\
& 24 & 17.7 & -0.3 & 0.0098 \\
& 4 & 10.2 & -0.4 & $<0.0001$ \\
\hline
\end{tabular}

Linear model: $\mathrm{y}=a+b \mathrm{x}$, in which $\mathrm{x} \geq 5.6 \mathrm{mg} \mathrm{L}^{-1}$.

(syn. P. parasitica), P. citrophthora and T. basicola [17] and $P$. cactorum [15]. Second, mycelial growth has a clear optimal oxygen level typically well below $21.0 \%$, which distinguishes this group from those of the first pattern. Examples of this group included $A$. euteiches that had optimal growth at 5.0\% [24]. Third, mycelial growth increases with increasing atmospheric oxygen only to a concentration, above which results in no further growth benefits. This pattern is illustrated by $P$. ultimum, of which mycelial growth was reduced at oxygen concentration of $1.3 \%$ but was the same for all oxygen levels from $4.0 \%$ to $21.0 \%$ [25].

It is unclear how the elevated concentrations of dissolved oxygen affected zoospore survival of different species. In this study we did observe that zoospores of $P$. nicotianae, $P$. pini and $P$. tropicalis remained motile for more than $2 \mathrm{~h}$ after their release from sporangia while the most zoospores of $P$. megasperma had already encysted before they were added to the $500-\mathrm{ml}$ volume at the various dissolved oxygen concentrations. It is reasonable to assume that motile zoospores are more vulnerable to environmental stresses including elevated concentrations of dissolved oxygen or hyperoxia than those encycled ones with cell wall.
It is worth of noting that zoospores of $P$. nicotianae died instantly in a 9.5-L fish tank being bubbled with oxygen at $0.5 \mathrm{~L} \mathrm{~min}^{-1}$ for $20 \mathrm{~min}$ under a separate experiment [22]. The dissolved oxygen concentration in this fish tank was estimated to be over $27.3 \mathrm{mg} \mathrm{L}^{-1}$ according to the formula developed above. It also was previously reported that hyperoxia suppressed fungi and bacteria $[29,30]$.

Artificial oxygenation of irrigation water for pathogen mitigation may not be economically feasible. However, dissolved oxygen concentration in irrigation reservoirs can naturally rise up to $26.5 \mathrm{mg} \mathrm{L}^{-1}$ due to phytosynthetic activities [13]. Zoospores are the principal, if not

Table 3 Linear regression analyses of colony counts (y) and levels $(x)$ of dissolved oxygen reduction from that in the control Hoagland's solution by Phytophthora species and exposure time ${ }^{z}$

\begin{tabular}{|c|c|c|c|c|}
\hline Species & Exposure (h) & Intercept (a) & Slope $(b)$ & $P$ \\
\hline \multirow[t]{7}{*}{ P. megasperma } & 0 (10 min) & 18.2 & -1.0 & 0.0936 \\
\hline & 2 & 11.3 & -0.2 & 0.6267 \\
\hline & 4 & 9.9 & -0.8 & 0.0104 \\
\hline & 8 & 7.4 & -0.3 & 0.2903 \\
\hline & 24 & 8.4 & -0.7 & 0.0292 \\
\hline & 48 & 7.6 & -0.9 & 0.0015 \\
\hline & 72 & 4.5 & -0.3 & 0.0724 \\
\hline \multirow[t]{7}{*}{ P. nicotianae } & 0 & 7.8 & 0.8 & 0.1067 \\
\hline & 2 & 25.0 & -1.2 & 0.0548 \\
\hline & 4 & 28.5 & -2.6 & 0.0008 \\
\hline & 8 & 12.3 & -0.4 & 0.4421 \\
\hline & 24 & 5.1 & -0.2 & 0.4100 \\
\hline & 48 & 3.6 & 0.0 & 0.8670 \\
\hline & 72 & 2.2 & 0.1 & 0.3973 \\
\hline \multirow[t]{7}{*}{ P. pini } & 0 & 9.1 & 0.4 & 0.2462 \\
\hline & 2 & 32.6 & -0.3 & 0.6893 \\
\hline & 4 & 37.2 & -2.1 & 0.0002 \\
\hline & 8 & 20.8 & -1.3 & $<0.0001$ \\
\hline & 24 & 14.4 & -0.8 & 0.0034 \\
\hline & 48 & 7.4 & -0.3 & 0.2382 \\
\hline & 72 & 8.3 & -0.5 & 0.0313 \\
\hline \multirow[t]{7}{*}{ P. tropicalis } & 0 & 27.8 & -1.8 & 0.0156 \\
\hline & 2 & 31.4 & -1.3 & 0.0749 \\
\hline & 4 & 29.7 & -0.3 & 0.6712 \\
\hline & 8 & 22.5 & -0.1 & 0.8042 \\
\hline & 24 & 7.8 & -0.3 & 0.1730 \\
\hline & 48 & 0.7 & 0.4 & 0.0008 \\
\hline & 72 & 0.4 & 0.2 & 0.0079 \\
\hline
\end{tabular}

Linear model: $\mathrm{y}=a+b \mathrm{x}$, in which $\mathrm{x}=5.3$ - meter readings of dissolved oxygen in the Hoagland's solutions after being bubbled with pure nitrogen, so $0 \leq \mathrm{x} \leq 5.3 \mathrm{mg} \mathrm{L}^{-1}$. 
sole, dispersal and infective propagules of Phytophthora and Pythium species in recycling irrigation systems [31-35]. Thus, the results of present study, along with those of previous studies [15,17,21,24,25,27,28], help understand the dynamics of these pathogens in irrigation reservoirs under hyperoxia conditions [36,37].

\section{Effect of low concentrations of dissolved oxygen on zoospore survival}

As in the dissolved oxygen elevation assays, the greatest colony counts in the control bottles occurred at 10-min exposure for P. megasperma and at 2- or 4-h exposure for the other three species (Table 3).

Zoospore survival of the four species assessed in this study also was negatively impacted by low concentrations of dissolved oxygen in two distinct patterns (Table 3). One pattern is represented by P. megasperma and $P$. pini. The impact on these two species generally occurred at 4-h or longer exposures at which their colony counts decreased with increasing level of dissolved oxygen reduction from the normal concentration of $5.3 \mathrm{mg} \mathrm{L}^{-1}$ in the control Hoagland's solution. The greatest rate of decrease in colony counts occurred at 48-h exposure for $P$. megasperma at 0.9 colony per unit of dissolved oxygen reduction $(P=0.0015)$ and at 4-h exposure for $P$. pini at $2.1(P=0.0002)$. Phytophthora nicotianae and $P$. tropicalis showed an exactly opposite pattern. The colony counts decreased with increasing level of reduction in dissolved oxygen concentration at both 2- and 4-h exposures for P. nicotianae, 10-min and 2-h exposures for $P$. tropicalis.

These results indicate that $P$. nicotianae and $P$. tropicalis are more prone than $P$. megasperma and $P$. pini to hypoxia stress in aquatic environments. They help understand the more consistent and greater recoveries of $P$. megasperma and $P$. pini than other major plant pathogens including $P$. nicotianae and $P$. tropicalis in irrigation systems [5,36,37]. Nevertheless, zoospore survival of all four species decreased with increasing intensity of hypoxia. Dissolved oxygen concentration in surface water of irrigation reservoirs can be as low as $0.3 \mathrm{mg} \mathrm{L}^{-1}$ [13]. This degree of hypoxia is likely to have more pronounced impact on the survival of zoospores in irrigation systems than what observed in this study. The results of present study are critical to understanding the population dynamics of Phytophthora species in irrigation reservoirs during hypoxia conditions [36,37].

\section{Conclusions}

In this study we showed for the first time the zoosporic responses to oxygen stress of four economically important species of Phytophthora in a simulated aquatic system. Zoospores of these species survived the best in the control solutions at dissolved oxygen concentrations of
5.3 to $5.6 \mathrm{mg} \mathrm{L}^{-1}$. Zoospore survival rate decreased with increasing intensity of hyperoxia and hypoxia conditions, depending upon Phytophthora species and exposure time. This study also demonstrated that P. megasperma had decreasing colony counts with increasing exposure hours from zero to $24 \mathrm{~h}$ while the other three species (P. nicotianae, P. pini and P. tropicalis) had the greatest colony counts at 2 and $4 \mathrm{~h}$ during the first $24 \mathrm{~h}$ of both elevated and low dissolved oxygen assays. Once again, this study demonstrated that zoospore mortality increases with increasing number of exposure days as did in previous studies $[6,7,9]$. This natural zoospore decline process was enhanced under hyperoxia and hypoxia conditions. These findings suggest that seasonal and diurnal fluctuations of water quality including dissolved oxygen $[13,38]$ more than likely had contributed to the population decline of Phytophthora species along the water path in the same agricultural reservoirs [36,37]. These findings advanced our understanding of aquatic ecology of Phytophthora species. They also provided an important basis for pathogen risk avoidance and mitigation by designing better recycling irrigation systems and modifying existing systems to prolong runoff water turnover time.

\section{Competing interests}

The authors declare that they have no competing interests.

\section{Authors' contributions}

PK designed and performed the experiments. PK and $\mathrm{CH}$ analyzed the data and wrote the manuscript together. Both authors read and approved the final manuscript.

\section{Acknowledgements}

This study was supported in part by a grant from the USDA National Institute of Food and Agriculture-Specialty Crop Research Initiative (Agreement \#: 2010-51181-21140).

Received: 27 January 2014 Accepted: 30 April 2014 Published: 13 May 2014

\section{References}

1. Blackwell E: Species of Phytophthora as water moulds. Nature 1944, 153:496.

2. Deacon JW, Donaldson SP: Molecular recognition in the homing responses of zoosporic fungi, with special reference to Pythium and Phytophthora. Mycol Res 1993, 97:1153-1171.

3. Duniway JM: Water relation of water molds. Ann Rev Phytopathol 1979, 17:431-460.

4. Erwin DC, Ribeiro OK: Phytophthora Diseases Worldwide. St Paul, MN, USA: APS Press; 1996.

5. Hong CX, Moorman GW, Wohanka W: Buettner C (eds.): Biology, Detection and Management of Plant Pathogens in Irrigation Water. St. Paul, MN, USA: APS Press; 2014.

6. Kong P, Lea-Cox JD, Hong CX: Effect of electrical conductivity on survival of Phytophthora alni, P. kernoviae and P. ramorum in a simulated aquatic environment. Plant Pathol 2012, 61:1179-1186.

7. Kong P, Moorman GW, Lea-Cox JD, Ross DS, Richardson PA, Hong CX: Zoosporic tolerance to $\mathrm{pH}$ stress and its implications for Phytophthora species in aquatic ecosystems. Appl Environ Microbiol 2009, 75:4307-4314.

8. Werres S, Wagner S, Brand T, Kaminski K, Seipp D: Survival of Phytophthora ramorum in recirculating irrigation water and subsequent infection of Rhododendron and Viburnum. Plant Dis 2007, 91:1034-1044. 
9. Kong P, Lea-Cox JD, Moorman GW, Hong CX: Survival of Phytophthora alni, Phytophthora kernoviae, and Phytophthora ramorum in a simulated aquatic environment at different levels of pH. FEMS Microbiol Lett 2012, 332:54-60.

10. Kong P: Carbon dioxide as a potential water disinfestant for Phytophthora disease risk mitigation. Plant Dis 2013, 97:369-372.

11. Ahonsi MO, Banko TJ, Doane SR, Demuren AO, Copes WE, Hong CX: Effects of hydrostatic pressure, agitation and $\mathrm{CO} 2$ stress on Phytophthora nicotianae zoospore survival. Pest Manag Sci 2010, 66:696-704.

12. Jantzen PG: Investigating factors that affect dissolved oxygen concentraton in water. Amer Biol Teach 1978, 40:346-352.

13. Hong CX, Lea-Cox JD, Ross DS, Moorman GW, Richardson PA, Ghimire SR, Kong $\mathrm{P}$ : Containment basin water quality fluctuation and implications for crop health management. Irrig Sci 2009, 29:485-496.

14. Fenchel T, Finlay BJ: Ecology and Evolution in Anoxic Worlds. Oxford, UK: Oxford University Press; 1995.

15. Covey RP: Effect of oxygen tension on the growth of Phytophthora cactorum. Phytopathology 1970, 60:358-359.

16. Mitchell DJ, Zentmyer GA: Effects of oxygen and carbon dioxide tensions on growth of several species of Phytophthora. Phytopathology 1971, 61:787-791.

17. Klotz LJ, Stolzy LH, De Wolfe TA: Oxygen requirements of three rootrotting fungi in a liquid medium. Phytopathology 1963, 53:302-305.

18. Mitchell DJ, Zentmyer GA: Effects of oxygen and carbon dioxide tensions on sporangium and oospore formation by Phytophthora spp. Phytopathology 1971, 61:807-811.

19. Dukes PD, Apple JL: Effect of oxygen and carbon dioxide tension on growth and inoculum potential of Phytophthora parasitica var. nicotianae. Phytopathology 1965, 55:666-669.

20. Burgess T, McComb J, Hardy G, Colquhoun I: Influence of low oxygen levels in aeroponics chambers on eucalypt roots infected with Phytophthora cinnamomi. Plant Dis 1998, 82:368-373.

21. Curtis DS, Zentmyer GA: Effect of oxygen supply on Phytophthora root rot of avocado in nutrient solution. Amer J Bot 1949, 36:471-474

22. Kong $P$, Lea-Cox JD: Water quality dynamics and influences on pathogen mitigation in irrigation reservoirs. In Biology, Detection and Management of Plant Pathology in Irrigation Water. Edited by Hong CX, Moorman GW, Wohanka W, Buettner C. St Paul, MN, USA: APS Press; 2014:333-346.

23. Ferguson AJ, Jeffers SN: Detecting multiple species of Phytophthora in container mixes from ornamental crop nurseries. Plant Dis 1999 83:1129-1136.

24. Sherwood RT, Hagedorn DJ: Effect of oxygen tension on growth of Aphanomyces euteiches. Phytopathology 1961, 51:492-493.

25. Brown GE, Kennedy BW: Effect of oxygen concentration of Pythium seed rot of soybean. Phytopathology 1966, 56:407-408.

26. Klotz $L$, Stolzy $L H$, DeWolfe TA: A method for determining the oxygen requirement of fungi i liquid media. Plant Dis Reptr 1962, 46:606-608.

27. Fraedrich SW, Tainter FH: Effect of dissolved oxygen concentration on the relative susceptibility of shortleaf and loblolly pine root tips to Phytophthora cinnamomi. Phytopathology 1989, 79:1114-1118.

28. Curtis DS, Chapman HD, Zentmyer GA: Resume of investigations concerning the oxygen requirements of avocado seedlings including a study of interrelations to nitrite and Phytophthora cinnamomi. CA Avocado Soc Yearbook 1949, 1949:155-165.

29. Caldwell J: Effects of high partial pressures of oxygen on fungi and bacteria. Nature 1965, 206:321-323.

30. Gottlieb SF, Pakman LM: Effect of high oxygen tension on the growth of selected, aerobic, Gram-negative, pathogenic bacteria. J Bacteriol 1968, 95:1003-1010.

31. Charlton ND, von Broembsen SL: Survival, settling, and lateral dispersal of encysted zoospores of Phytophthora spp. in captured irrigation runoff. Phytopathology 2000, 90:S13.

32. Pittis JE, Colhoun J: Isolation and identification of pythiaceous fungi from irrigation water and their pathogenicity to Antirrhinum, tomato and Chamaecyparis lawsoniana. Phytopath Z 1984, 110:301-318.

33. Stanghellini ME, Kim DH, Rasmussen SL, Rorabaugh PA: Control of root rot of peppers caused by Phytophthora capsici with a nonionic surfactant. Plant Dis 1996, 80:1113-1116.

34. Stanghellini ME, Rasmussen SL, Kim DH, Rorabaugh PA: Efficacy of nonionic surfactants in the control of zoospore spread of Pythium aphanidermatum in a recirculating hydroponic system. Plant Dis 1996, 80:422-428.

35. Thomson SV, Allen RM: Occurrence of Phytophthora species and other potential plant pathogens in recycled irrigation water. Plant Dis Reptr 1974, 58:945-949.

36. Ghimire SR, Richardson PA, Kong P, Hu JH, Lea-Cox JD, Ross DS, Moorman GW, Hong CX: Distribution and diversity of Phytophthora species in nursery irrigation reservoir adopting water recycling system during winter months. J Phytopathol 2011, 159:713-719.

37. Hong CX, Richardson PA, Kong P: Decline in Phytophthora population with increasing distance from runoff water entrance in a retention pond. Phytopathology 2003, 93:\$36.

38. Hong CX, Richardson PA, Ghimire SR, Kong P, Moorman GW, Lea-Cox JD, Ross DS: Water quality dynamics in irrigation runoff retention basins and its practical implications for plant health management. Phytopathology 2008, 98:S68.

doi:10.1186/1471-2180-14-124

Cite this article as: Kong and Hong: Oxygen stress reduces zoospore survival of Phytophthora species in a simulated aquatic system. BMC Microbiology 2014 14:124.

\section{Submit your next manuscript to BioMed Central and take full advantage of:}

- Convenient online submission

- Thorough peer review

- No space constraints or color figure charges

- Immediate publication on acceptance

- Inclusion in PubMed, CAS, Scopus and Google Scholar

- Research which is freely available for redistribution 